\section{Distribution of human T-lymphotropic virus type I among blood donors: a nationwide Brazilian study}

Previous studies have demonstrated the presence of human T-lymphotropic virus type I (HTLV-I) and/or HTLV type II (HTLV-II) in certain populations in Brazil. ${ }^{1-6}$ Data on qualified blood donors are limited primarily to those in the southeast region of Brazil, while the country's $8,400,000$ square miles include diverse geographic, climatic, and sociodemographic characteristics.

To assist in the formulation of public health policies for blood donors, we conducted the following seroprevalence study. Between July and September 1993, blood samples were collected from 5842 blood donors in five state capitals. All individuals fulfilled criteria for blood donation (i.e., they were 18-60 years old and they had no reported risk behavior for sexually transmitted diseases). Samples were not linked to donor identification. To avoid repeated sampling of the same donor, the duration of the study was limited to 60 days, which is the permissible interval between donations.

Sera were screened for antibodies to HTLV-I/II by using a recombinant HTLV-I env enzyme-linked immunosorbent assay and were confirmed by an HTLV-I recombinant p21 envenhanced Western blot (Cambridge Biotech Corp., Worcester, MA). Serologic discrimination between HTLV-I and HTLV-II was performed by using specific synthetic peptides (Select HTLV, Coulter Corp., Hialeah, FL). All Western blot samples reacted with a synthetic peptide sequence derived from HTLVI. Results were interpreted according to manufacturers' instructions.

The overall HTLV-I seroprevalence was 0.41 percent $(95 \%$ CI, 0.25-0.58) (Table 1). The city of Salvador, which has sociodemographic characteristics like those of some sub-Saharan cities, had the highest seroprevalence (1.35\%). Unexpectedly, a relatively low HTLV-I seroprevalence $(0.08 \%)$ was found in Manaus (capital of the Amazonas State) in the Amazon Basin.

None of the 5842 samples was confirmed positive for antiHTLV-II, although a previous report described a relatively high HTLV-II seroprevalence among Gé-speaking Cayapo and Kraho Indians in Central Brazil, ${ }^{\prime}$ as well as a low HTLV-II seroprevalence $(0.03 \%)$ in Saõ Paulo. ${ }^{5}$ The discrepancy be- tween the absence of anti-HTLV-II in our study of blood donors in state capitals and the presence of anti-HTLV-II reported by others may be explained by 1 ) the possibility that we screened an insufficient number of donors in our study, as suggested by the low HTLV-II seroprevalence $(0.03 \%)$ found by others, ${ }^{5}$ and 2) the fact that individuals living in Amazon Basin metropolitan areas have not mixed, recently or in the past, with the relatively isolated Brazilian Indians.?

Our findings indicate that a more comprehensive seroprevalence study is needed to determine the prevalence of HTLV-II infection among Brazil's diverse and distinct populations. Ideally, nationwide screening of blood donors should be continued to prevent the spread of HTLV-I and HTLV-II by transfusion, or, at least, screening should be continued in the highly endemic area. Finally, to facilitate these measures in developing countries, there is an urgent need for inexpensive methods of blood screening, confirmation, and discrimination of anti-HTLV-I and -II.

B. Galvão-Castro, MD LASP-FIOCRUZ, Salvador

L. Loures, L.G.M. Rodriques, A. Sereno PNDST/AIDS, MS. Brasília

O.C. Ferreira, Jr. Serviço de Hemoterapia Hospital Albert Einstein São Paulo, SP L.G.P. Franco HEMORIOA, Rio de Janeiro M. Muller HEMOBA, Salvador D.A.Sampaio HEMOSC, Florianópolis A. Santana HEMOPE, Recife L.M. Passos HEMOAM, Manaus F. Proietti Departmento de Medicina Preventativa e Social UFMG Belo Horizonte MG Brazil

\section{REFERENCES}

TABLE 1. Geographic distribution of HTLV-I among Brazilian blood donors

\begin{tabular}{llccccr}
\hline Region & \multicolumn{1}{c}{ City } & Number & ELISA* & $\begin{array}{c}\text { Western } \\
\text { blot-positive }\end{array}$ & $\begin{array}{r}\text { Prevalence } \\
(\%)\end{array}$ & $95 \% \mathrm{Cl}$ \\
\hline North & Manaus & 1200 & 5 & 1 & 0.08 & $0.00-0.25$ \\
Northeast & Recife & 1200 & 16 & 4 & 0.33 & $0.01-0.66$ \\
& Salvador & 1040 & 20 & 14 & 1.35 & $0.65-2.05$ \\
Southeast & Rio de Janeiro & 1200 & 10 & 4 & 0.33 & $0.07-0.66$ \\
South & Florianopolis & 1200 & 2 & 1 & 0.08 & $0.00-0.25$ \\
$\quad$ & 5840 & 53 & 24 & 0.41 & $0.25-0.58$ \\
\hline Total & & 58 & & \\
* Repeatably reactive enzyme-linked immunosorbent assay.
\end{tabular}

1. Maloney EM, Biggar RJ, Neel JV, et al. Endemic human T cell lymphotropic virus type Il infection among isolated Brazilian Amerindians. J Infect Dis 1992;166:100-7.

2. Matutes E, Schulz T, Andrada-Serpa MJ, et al. Report of the Second International Symposium on HTLV in Brazil. Leukemia 1994;8:92-4. 
3. Gabbai AA, Bordin JO, Vieira-Filho JP, et al. Selectivity of human T-lymphotropic virus type I (HTLV-I) and HTLV-II infection among different populations in Brazil. Am J Trop Med Hyg 1993;49:664-71.

4. Proieti FA, Lima-Martins MV, Passos VM, et al. HTLV-I/II seropositivity among eligible blood donors from Minas Gerais state, Brazil. Vox Sang 1994;67:77.

5. Ferreira OC Jr, Vaz RS, Carvalho MB, et al. Human T-lymphotropic virus type $I$ and type II infections and correlation with risk factors in blood donors from Saõ Paulo, Brazil. Transfusion 1995;35:258-63.

6. Santos JI, Lopes MA, Deliège-Vasconcelos E, et al. Seroprevalence of HIV, HTLV-I/II and other perinatally transmitted pathogens in Salvador, Bahia. Rev Inst Med Trop Saō Paulo 1995;31:343-8.

7. Salzano FM, Neel JN, Gershowitz H, Migliazza EC. Intra and intertribal genetics within a linguistic group; the Ge-speaking Indians of Brazil. Am J Physiol Anthropol 1977;47:337-47.

\section{Sensitivity analysis of cost-effectiveness of mechanical barrier system to reduce risk of a mistransfusion}

The possibility of allocating resources to improve health care (innovative treatments and/or new technology) in terms of cost estimates of life years saved is appealing to me. Recently, AuBuchon and Littenberg ${ }^{l}$ analyzed the cost-effectiveness of using a mechanical barrier system to reduce the risk of mistransfusion in terms of an acceptable cost in life years. In their Results section, they mentioned that a mechanical barrier system becomes a less expensive alternative if the legal cost for a fatal reaction exceeds $\$ 725,000$ and the misidentification risk exceeds 1 in 16,700. The only way in which I can interpret these claims is to assume 1) that $\$ 725,000$ corresponds to a misidentification base-case risk of 1 in 24,000 (not stated), and 2) that 1 in 16,700 refers to a base-case legal cost of $\$ 500,000$ per fatal reaction (not stated). Also implicit in the model is the legal costs of two equally expensive nonfatal reactions for every fatal misidentification reaction. The authors go on to conclude that, at a $\$ 50,000$ cost-effectiveness level, the barrier system is justified when the legal costs exceed $\$ 540,000$ and when the chance of misidentification exceeds 1 in 22,650. In both cases, I believe the conjunction should be "or" instead of "and." I submit this clarification in an effort to facilitate a better understanding of the useful cost-effectiveness sensitivity analysis model.

Victor A. Silva, MD Medical Director, Blood Bank Grady Health System 80 Butler Street $S E$ Atlanta, GA30335-3801

\section{REFERENCE}

1. AuBuchon JP, Littenberg B. A cost-effectiveness analysis of the use of a mechanical barrier system to reduce the risk of mistransfusion. Transfusion 1996;36:222-6.
The above letter was sent to Dr: AuBuchon, who offered the following response.

Dr. Silva's questions pertain to threshold values for key variables in the analysis of the cost-effectiveness of a barrier system to prevent mistransfusion. The results noted are those of one-dimensional analyses; that is, the value of only one variable at a time was altered, while the others were kept at their "base-case" values.

As complex as cost-effectiveness models can be, the explanation of their construction and manipulation can be even more problematic. Dr. Silva believes that the conjunction "or" is more appropriate in descriptions of the results of the model, and I have no objection to this suggestion.

James P. AuBuchon, MD

Professor of Pathology and Medicine Department of Pathology

Dartmouth-HitchcockMedical Center One Medical Center Drive Lebanon, NH 03756

\section{Decrease in frequency of transfusion fatalities}

Transfusions may have serious and fatal complications. In New York State, all adverse transfusion outcomes are reportable to the New York State Department of Health (NYSDOH). All transfusions in the United States that may have contributed to the death of a patient or donor are reportable to the Food and Drug Administration (FDA). We searched both organizations' databases and evaluated the information. Data from January 1990 to June 1995 were collected at NYSDOH and those from January to December 1994 at FDA. The following categories were used for sorting the fatality reports: acute hemolytic reactions due to $\mathrm{ABO}$-incompatible allogeneic red cells, acute hemolytic reactions due to $\mathrm{ABO}$-incompatible red cells thought to be autologous, delayed hemolytic transfusion reactions, hemolytic anti-A in platelet components, transfusion-related acute lung injury, graft-versus-host disease, sepsis, transfusion-associated hepatitis, pulmonary edema, air embolism during intraoperative blood recovery and/or postoperative blood recovery, and death during or after plasma exchange.

Because the number of transfusions in New York must be reported to $\mathrm{NYSDOH}$, an accurate denominator was available. To calculate event rates for the United States, recent, published estimates of total transfusions were used. ${ }^{1}$ The results are shown in Table 1. Two cases of sepsis were due to 1) Serratia liquifaciens in a red cell unit and 2) coagulase-negative Staphylococcus in a platelet unit. We believe this rate to be a serious underestimation of the true rate of transfusion-associated sepsis. Blood recovered intraoperatively and/or postoperatively had the highest risk for adverse outcome per procedure, with the primary risk being air embolism associated with administration of recovered blood under pressure.

The primary risk for transfusion-associated death continues to be the administration of ABO-incompatible red cells 